\title{
Insulin and Glucagon Secretion by Islets Isolated from Fetal and Neonatal Rats
}

\author{
F. Sodoyez-Goffaux ${ }^{1}$, J. C. Sodoyez ${ }^{1}$, Cl. J. De $\operatorname{Vos}^{1}$, and P. P. Foà ${ }^{2}$ \\ ${ }^{1}$ Departments of Pediatrics and Internal Medicine, University of Liège, Liège, Belgium and \\ 2 Department of Physiology, Wayne State University, Detroit, Michigan, USA
}

\begin{abstract}
Summary. Islets were isolated by mild collagenase digestion and microdissection from rat fetuses 2 days before term and pups 1 or 2 days after birth and their insulin and glucagon secretion studied in vitro. Fetal B cells were stimulated by $16.7 \mathrm{mmol} / 1$ glucose, $20 \mathrm{mmol} / 1$ leucine or $20 \mathrm{mmol} / \mathrm{l}$ arginine. Fetal A cells were not affected by glucose or leucine, but were significantly stimulated by arginine. Somatostatin abolished the effect of arginine on both IRI and IRG output. Neonatal islets proportionally released more insulin and glucagon than their fetal counterparts, but reacted to the tested agents in a similar fashion. During the perinatal period, pancreatic insulin storage increased at a higher rate than that of glucagon. It is concluded that fetal B cells are equipped with sensors to a variety of agents and able to modulate their secretory rate according to the concentration of these agents. A cells are reactive to arginine 2 days before term but do not become glucose reactive until several days after birth.
\end{abstract}

Key words: Insulin, glucagon, rat, fetus, neonate, isolated islets, glucose, arginine, leucine, somatostatin.

Whereas insulin (IRI) secretion has been extensively studied during the perinatal period in the rat, much less information is available concerning the regulation of glucagon (IRG) secretion by the fetal and neonatal rat pancreas. Glucose had little or no stimulatory effect on the IRI secretion of fetal pancreatic pieces $[1,2]$, cultured explants of fetal pancreas [3] or isolated fetal islets $[4,5]$. The glucose stimulated insulin release mechanism was reported to mature after birth $[1,2]$ or after one week culture in a high glucose medium [5]. A few authors, however, observed that glucose significantly enhanced the rate of IRI secretion of fetal pancreatic pieces or cultured explants $[6,7]$ and the rate of IRI biosynthesis by fetal rat islets [8]. Leucine and arginine had no stimulatory effect on the IRI secretion of fetal pancreas removed on the $18^{\text {th }}$ day of gestation and incubated either immediately or following a 4 day culture [9]. The addition of $10 \mathrm{mmol} / \mathrm{l}$ caffeine to the incubation medium unmasked the secretagogue effect of these 2 amino acids [9]. After birth, arginine enhanced both IRI and IRG secretion [10].

Experiments performed in various species lent support to the contention that fetal A cells were also immature. In particular, in the newborn rat, glucose did not modulate IRG secretion either in vivo [11] or in vitro $[10,12]$, whereas somatostatin significantly lowered plasma IRG concentration [11]. To our knowledge, data concerning the effect of glucose and somatostatin on fetal rat A cells are presently unavailable.

It could perhaps be concluded that during the perinatal period, the endocrine pancreas undergoes critical maturation steps possibly related to the switch from intra- to extrauterine life. In order to better define these maturation steps, we have compared the IRI and IRG secretion of rat islets isolated 2 days before term and 1 day after birth.

\section{Materials and Methods}

Female albino rats weighing 230 to $260 \mathrm{~g}$ were caged overnight with a male and the exact duration of pregnancy was known with a $12 \mathrm{~h}$ error. On the $20^{\text {th }}$ day of gestation, the pregnant rats were anaesthetized with nembutal $(60 \mathrm{mg} / \mathrm{kg}, \mathrm{sc})$, the pups were rapidly removed, their pancreases dissected and transferred into $2 \mathrm{ml}$ of Hanks solution to which $1 \mathrm{mg}$ of collagenase (Clostridium histolyticum, lot 1406317, Boehringer, West Germany) was added. Other pups were killed by decapitation 24 to $48 \mathrm{~h}$ after spontane- 
2 days preterm fetuses
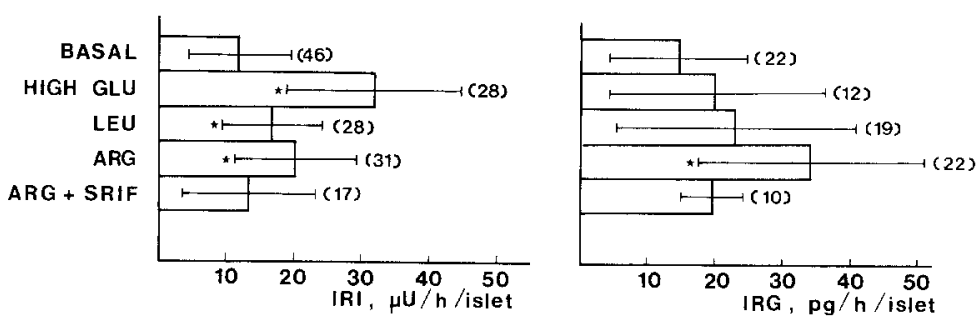

24 to 48 hours after birth
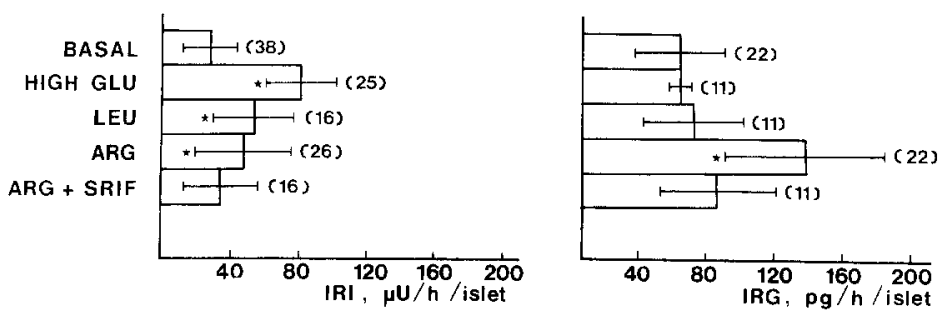

ous delivery and their pancreases removed. After vigorous shaking for $10 \mathrm{~min}$ at $37^{\circ}$, collagenase digestion was stopped by ice cold Hanks solution and the islet suspension was washed 3 times. Using a dissecting microscope, the small fetal islets were best seen on a black background with lateral light. Since collagenase digestion was kept minimal, most islets were still attached to exocrine or connective tissue. They were carefully freed of extraneous tissue by microdissection, handpicked with a wire loop and transferred to Erlenmeyer flasks containing $2 \mathrm{ml}$ of ice cold incubation medium kept under a $95 \% \mathrm{O}_{2}+5 \% \mathrm{CO}_{2}$ atmosphere. Each flask received 10 islets and was incubated for $60 \mathrm{~min}$ at $37^{\circ}$ under gentle shaking. At the end of the incubation, the medium was aspirated through a Millipore filter holder equipped with a nylon filter of $5 \mu \mathrm{m}$ pore, selected because it retained free cells but did not adsorb insulin. The cell-free medium was immediately frozen at $-25^{\circ}$. Ten additional islets were directly transferred to a Potter homogenizer containing $2 \mathrm{ml}$ of acid ethanol and the homogenate allowed to stand $24 \mathrm{~h}$ at $4^{\circ}$. The incubation medium consisted of Krebs-Ringer bicarbonate buffer supplemented with $10 \mathrm{mg} / \mathrm{ml}$ bovine serum albumin (crystallized, Sigma, St Louis) and $2.8 \mathrm{mmol} / 1$ glucose. When indicated, this basic medium was enriched by the addition of $13.9 \mathrm{mmol} / 1$ glucose, $20 \mathrm{mmol} / 1 \mathrm{~L}$-leucine or $20 \mathrm{mmol} / \mathrm{l} \mathrm{L}$ arginine, with or without $50 \mathrm{ng} / \mathrm{ml}$ cyclic somatostatin (Beckman, Geneva, lot C0513).

After appropriate dilution, IRI and IRG concentrations were measured by standard immunoassay procedures $[13,14]$ using a rat insulin standard (Novo Industri AS, Copenhagen, lot R 171) and a pork glucagon standard (Novo Industri AS, lot G 501575). The antiglucagon serum (AGS 10) was prepared by P. P. Foà and $\left[{ }^{125} \mathrm{I}\right]$ monoiodoglucagon was purchased from New England $\mathrm{Nu}$ clear, Boston, Mass.

Differences between groups were evaluated by Student's $t$-test.

\section{Results}

The insulin and glucagon secretions of islets isolated from fetuses after 20 days of gestation and from pups aged 24 to $48 \mathrm{~h}$ are illustrated in Fig. 1. Two days before term, IRI output was increased 3 fold by $16.7 \mathrm{mmol} / 1$ glucose and to a lesser extent by $20 \mathrm{mmol} / 1$ leucine or arginine. The stimulatory effect of arginine was almost completely abolished by $50 \mathrm{ng} / \mathrm{ml}$ somatostatin. Glucagon secretion was not significantly altered by high glucose or leucine. Arginine enhanced the IRG output of fetal islets and this effect was abolished by somatostatin. Islets isolated from newborn rats reacted in a similar fashion, although they released about 2.5 times more insulin and 4 times more glucagon than the fetal islets.

The islets and total pancreas IRI and IRG contents of both age groups are summarized in Table 1 . During the perinatal period, the pancreatic storage of insulin appeared to increase at a higher rate than that of glucagon.

After $1 \mathrm{~h}$ incubation in the presence of $2.8 \mathrm{mmol} /$ 1 glucose, both fetal and neonatal islets released an amount of glucagon equivalent to approximately $2 \%$ of their content. The percentage of insulin released in $1 \mathrm{~h}$ was also about $2 \%$ in neonatal islets, but almost $4 \%$ in fetal islets.

Table 1. IRI and IRG extractable from isolated islets and total pancreas of 2 days preterm fetuses and pups aged 24 to $48 \mathrm{~h}$

$$
2 \text { days preterm } \begin{aligned}
& 24 \text { to } 48 \mathrm{~h} \text { after } \\
& \text { birth }
\end{aligned}
$$

Islet hormone content

IRI, $\mu \mathrm{U} /$ islet

IRG, pg/islet

$$
319 \pm 142(26) 1143 \pm 345(19)
$$$$
669 \pm 210 \text { (25) } 2446 \pm 1088(22)
$$

Pancreas hormone content

$$
\text { IRI, mU/pancreas } \quad 52 \pm 12(26) \quad 325 \pm 80(19)
$$

IRG, ng/pancreas

$147 \pm 65(22) \quad 576 \pm 210(18)$

Pancreas hormone concentration

$$
\begin{aligned}
& \text { IRI, } \mathrm{mU} / \mathrm{mg} \\
& 2.32 \pm 1.65(26) 11.0 \pm 6.8 \\
& \text { IRG, } \mathbf{n g} / \mathrm{mg} \\
& 6.85 \pm 2.82(22) \quad 16.0 \pm 4.8
\end{aligned}
$$

Mean $\pm S D$. Number of observations in parentheses 


\section{Discussion}

Fetal and neonatal islet cells qualitatively reacted to glucose, leucine, arginine and somatostatin as would adult cells, the only exception being that A cell secretion was not inhibited by a high glucose concentration. This peculiarity might be secondary to alteration in the cells during the process of islet isolation. Such an explanation seems unlikely since the functional integrity of these cells is evidenced by their reactivity to arginine and somatostatin. Before stating that fetal and neonatal A cells are completely glucose blind, one should, in addition, verify that glucagon secretion is not stimulated in a very low glucose medium and that the arginine stimulated IRG release is not inhibited by a high glucose concentration. In its present form however this finding is in agreement with those of Girard et al. and of Edwards et al. [11, 12]. Thus, B cell sensitivity to fuels and A cell sensitivity to arginine appear before the $20^{\text {th }}$ day of gestation, whereas A cell reactivity to glucose appears later, at least several days after birth.

Neonatal islets contain and release more insulin and glucagon than fetal islets and the IRI/IRG molar ratio of released hormones is slightly lower for the islets of newborn rats. The slight decrease of the released hormones molar ratio observed in vitro markedly contrasts with the dramatic changes of IRI and IRG plasma concentrations which occur at birth [11, 15]. These observations strongly suggest that, in vivo, changes in IRI and IRG secretion rates are not determined by intrinsic changes of the islets themselves but rather by modifications of their neuroendocrine and/or metabolic environment. At birth, cord cutting would remove the $B$ cell stimulating influence of the placenta [16] while, as suggested by Sperling et al. [17], postnatal stimulation of the adrenergic system would enhance glucagon and further depress insulin secretion.

Our data do not support the hypothesis that critical maturation steps take place in the endocrine pancreas during the perinatal period. We are tempted to conclude that late fetal islet cells should not be looked upon as ,not yet complete adult cells“. They are already equipped with receptors to a variety of substances and are able to modulate their secretion according to changes in their environment, of which the most dramatic occur at birth.

Acknowledgement. This work was supported by the National Fund for Scientific Research, Brussels, Belgium.

\section{References}

1. Asplund, K., Westman, S., Hellerström, C.: Glucose stimulation of insulin secretion from the isolated pancreas of foetal and newborn rats. Diabetologia 5, 260-262 (1969)
2. Sodoyez-Goffaux, F., Sodoyez, J. C., Foà, P. P.: Effects of gestational age, birth and feeding on the insulinogenic response to glucose and tolbutamide by fetal and newborn rat pancreas. Diabetes 20, 586-591 (1971)

3. Vecchio, D., Luyckx, A., Renold, A. E.: Culture d'organe de pancréas foetal de rat: II. Effets du glucose, d'un sulfamidé hypoglycémiant et du glucagon sur la libération de l'insuline. Helv. Physiol. Acta 25, 134-146 (1967)

4. Ågren, A., Andersson, A., Hellerström, C.: Effects of D-glyceraldehyde and D-glucose on the insulin release of pancreatic islets isolated from the newborn rat. FEBS Lett. 71, 185-188 (1976)

5. Hellerström, C., Lewis, N. J., Johnson, R., Freinkel, N.: Maturation of insulin release and phosphate metabolism in fetal rat islets maintained in tissue culture. Diabetes 27, 456 (1978)

6. de Gasparo, M., Pictet, R. L., Rall, L. B., Rutter, W. J.: Control of insulin secretion in the developing pancreatic rudiment. Dev. Biol. 47, 106-122 (1975)

7. Lambert, A. E., Kanazawa, Y., Halter, J. B., Orci, L., Rouiller, C., Renold, A. E.: Insulin release from fetal and newborn rat pancreas in vitro: role of the adenyl cyclase system. Acta Diabetol. Lat. 7, 229-261 (1970)

8. Asplund, K.: Effects of glucose on insulin biosynthesis in foetal and newborn rats. Horm. Metab. Res. 5, 410-415 (1973)

9. Lambert, A. E.: Biochemical and morphological studies of cultured fetal rat pancreas. Thesis, Univ. of Geneva, Switzerland, and Univ. of Louvain, Belgium 1970

10. Jarrousse, Cl., Rosselin, G.: Interaction of amino acids and cyclic AMP on the release of insulin and glucagon by newborn rat pancreas. Endocrinology 96, 168-177 (1975)

11. Girard, J. R., Kervran, A., Assan, R.: Functional maturation of the A cell in the rat. In: Early diabetes in early life. Camerini-Davalos, R. A., Cole, H. S. (Eds.), pp 57-71. New York, San Francisco, London: Academic Press 1975

12. Edwards, J. C., Asplund, K., Lundqvist, G.: Glucagon release from the pancreas of the newborn rat. J. Endocrinol. 54, 493-504 (1972)

13. Hales, C. N., Randle, P. J.: Immunoassay of insulin with insulin-antibody precipitate. Biochem. J. 88, 137-146 (1963)

14. Unger, R. H., Aguilar Parada, E., Muller, W. A., Eisentraut, A. M.: Studies of pancreatic alpha cell function in normal and diabetic subjects. J. Clin. Invest. 49, 837-848 (1970)

15. Blázquez, E., Sugase, R., Blázquez, M., Foà, P. P.: Neonatal changes in the concentrations of rat liver cyclic AMP and of serum glucose, free fatty acids, insulin, pancreatic and total glucagon in man and in the rat. J. Lab. Clin. Med. 83, 957-967 (1974)

16. Sodoyez-Goffaux, F. R., Sodoyez, J. C., De Vos, C. J.: Evidence for a placental role in rat fetal hyperinsulinism. Diabetes 27, 462 (1978)

17. Grajwer, L. A., Sperling, M. A., Sack, J., Fisher, D. A.: Possible mechanisms and significance of the neonatal surge in glucagon secretion: studies in newborn lambs. Pediatr. Res. 11, 833-836, (1977)

Received: September 19, 1977

and in revised form: September 14, 1978

Dr. F. Sodoyez-Goffaux

Department of Pediatrics

Hôpital de Bavière

University of Liège

66 Bld. de la Constitution

B-4020 Liège

Belgium 